\title{
DEMOCRACY UNDER SIEGE
}

\author{
Lawrence D. Bobo \\ Department of African and African American Studies and Department of Sociology, \\ Harvard University
}

"If ever freedom is lost in America, that will be due to the omnipotence of the majority driving the minorities to desperation and forcing them to appeal to physical force. We may then see anarchy, but it will have come as the result of despotism."

—Alexis de Tocqueville, Democracy in America (1848[1966], p. 260)

Democratic institutions are never more at risk than when a demagogue convinces a ruling majority that their way of life is in jeopardy. At such times, the stage is set for further marginalization of those already deemed internal threats to the social order. In addition, the rule of equality before the law may be sacrificed to the putative need to maintain unity and public safety; religious minorities in particular are likely to be cast under great suspicion; the open operation of a free press is likely to erode; and the expression of political dissent and the rights of minorities face increasing constriction. Left unchecked, these reinforcing trends move a democratic state toward becoming a despotic one.

It is little surprise then that a variety of actions by the Trump Administration have prompted deep anxiety in many quarters about the fate of American democracy. He promised not only a different policy agenda from the previous eight years of governance by Barack Obama, but quickly embarked on an unprecedented departure from the routine norms of Presidential conduct on numerous fronts. Trump's open antagonism toward and demonization of both undocumented Mexican immigrants and Muslims seeking entry to the U.S., his apparent sympathy with white nationalist activists, pardon for racial profiling Arizona Sheriff Joe Arpaio, renewed dedicated to a "War on Drugs," views of African immigrant immigrants as coming from "shithole" countries, and other policies that fueled the rise of racialized mass incarceration, are read in many quarters as returning America to the days of Herrenvolk Democracy.

For his part, de Tocqueville in his highly regarded assessment of American democracy expected that white and black would never meet one another as full equals. As he argued:

"Once one admits that whites and emancipated Negroes face each other like two foreign people on the same soil, it can easily be understood that there are only two

Du Bois Review, 14:2 (2017) 381-385.

(C) 2018 Hutchins Center for African and African American Research 1742-058X/18 \$15.00

doi:10.1017/S1742058X1800005X 
possibilities for the future: the Negroes and whites must either mingle completely or they must part.

I have already expressed my conviction concerning the first possibility. I do not think that the white and black races will ever be brought anywhere to live on a footing of equality.

But I think that the matter will be still harder in the United States than anywhere else. It can happen that a man with the above prejudices of religion, country, and race, and if that man is a king, he can bring about astonishing transformations in society; but it is not possible for a whole people to rise, as it were, above itself." (pp. 355-356)

To be sure, one need not fully embrace de Tocqueville's pessimism to admit that working out this matter of the mingling of white with black, as well as with those of other ethnoracial backgrounds, has proven a considerable challenge for American democracy.

The tenacity of racial inequality lends credence to claims that nothing has really changed for African Americans. Serious debate then occurs around just how much the post-civil rights era status of blacks differs from what it was in the pre-civil rights era, both over time in absolute terms and relative to their fellow white citizens. One arena of keenly focused inquiry is the standing of blacks within the economic order. Distinguished sociologist Franklin D. Wilson takes a comprehensive look at this question in terms of occupational status changes over time, across generations, and between blacks and whites. He gauges occupational standing not simply in terms of categorical placement (i.e., professional, versus technical, agricultural, etc). but in terms of the occupational status returns to a given level of education and in terms of the earnings returns to a given occupational status. Wilson compares successive decadal cohorts from 1910 to 1979 in relative occupational status of blacks and whites. His results raise serious questions for those pressing the claims that blacks have made relative gains on whites. Indeed, his analyses suggest that post-1940 black males lost ground relative to whites (even if general occupational upgrading was occurring) but that black women have enjoyed some (though unstable) relative gains on white women. In general, Wilson's work is a strong cautionary note about making totalizing claims about changes in the racial economic divide (Katz, Stern and Fader 2005).

In the political arena Barack Obama has often been characterized as a new, deracialized black politician. Indeed, some have suggested that his personal success came at the expense of substantive political progress for African Americans due to his putatively deracialized political commitments and willingness to play on anti-black stereotypes to curry white support (Harris 2012; Jeffries 2013; Glaude 2016; Dyson 2016). Politics and international relations scholar Richard Johnson calls for a more sophisticated and nuanced analysis of Obama's race politics. Drawing upon the work of Rogers Smith and Desmond King (Smith and King 2009; King and Smith 2011), Johnson argues that we must separate campaign strategy from substantive political beliefs and commitments. His archival work shows that Obama was long part of a "race conscious" political coalition rooted in his early organizing and activist days in Hyde Park, Chicago. While his electoral campaign exhibited some features of deracialization, this approach neither defined his personal philosophical outlooks nor policy goals while in power. That is, Obama governed in a manner clearly identified with the "race conscious" coalition characteristic of American liberal mainstream politics for much of the past four decades.

Four articles in this issue wrestle with the various ways that race places out in the arena of law enforcement and criminal justice. Political scientists Mintao Nie and Eric 
Waltenburg examine how and why race affects support for the U.S. Supreme Court. Scholars have long found that of the three branches of the federal government it is the judicial branch, particularly the Supreme Court, that enjoys highest perceived legitimacy. This perception is arguably rooted in beliefs about the objectivity, impartiality, and professionalism of the court, beliefs heavily reinforced by the way media typically report on the Supreme Court. Using data from a 2003 survey on "Blacks and the U.S. Supreme Court" they suggest that black media depart significantly from mainstream media in depiction of the courts. The more openly critical and less symbolically supportive view of the court appearing in many black media sources accounts for much the greater skepticism of African Americans toward the court.

Justin Pickett and Stephanie Bontrager Ryon analyze data from a 2014 sample of juvenile and adult criminal justice system workers in an effort to understand possible sources of a more critical, strong reform oriented view of how the system is operating. There results indicate that respondent race, the type of criminal justice frame the individual adopts (e.g., whether the criminal justice system is functioning in a harmful fashion), and perceptions of racial discrimination are the most influential factors. Sociologist Alicia Simmons sets out to develop systematic data on the number of police shootings of unarmed civilians and then assess when those shootings result in national news coverage. Her results indicate that the size of the black population in the area where the shooting occurs and the presence of documenting video play a major role in whether or not the police shooting of an unarmed Black person is covered by major news outlets.

Naa Oyo Kwate and Shatema Threadcraft advance a theoretical logic that attempts a substantial re-framing of our understanding of the policing practice known as "stop and frisk." Drawing on Foucaultian notions of biopower, particularly as extended by African political theorist Achielle Mbembe, they propose that "stop and frisk" must be read as a form of necropolitics. That is, they develop the case that extensive and almost exclusive intrusion of state police power of this kind into the lives for poor people of color becomes an exercise in controlling, degrading, and if need be, destroying black bodies.

Psychologist Hugo Canham aims to resuscitate and make relevant a concept of Black Rage (Baldwin 1963; Grier and Cobbs 1968) in understanding political events in pre- and post-apartheid South Africa. He suggests that acts of violence, property destruction and the like are often best understood as forms of protest; protest motivated by a sense of anger and rage cultivated under oppressive conditions of race and class inequality. He situates his claims in a literature spanning the U.S. and South African experiences. Critically, his claims are informed by a careful archival work exploring discursive personal narratives catalogued as part of the Truth and Reconciliation hearings in South Africa as well as by examination of collections of the visual representation of Black rage in political posters. He rejects a view of sometimes destructive protest behavior as irrational, apolitical, criminal behavior. Instead, he sees these actions as assertion of human dignity against the prevailing dehumanizing and marginalizing structure of racial oppression.

In a somewhat related piece $\mathrm{Naa}$ Oyo Kwate develops a theoretical argument about the importance of time to health outcomes and race disparities therein. We have grown accustomed to thinking of racialized spaces (e.g., segregated neighborhoods) as having an impact on health outcomes by influencing exposure to pollutants, to violent crime, to lower levels and quality of public services of many kinds. Inspired in part by philosopher Charles Mills distinction between white time and black time, Kwate suggests that time is a dimension of raced-social experience that must also be taken into account. Black time, thus, impose costs on bodies, to resources, and with regard to opportunities that also impinge on health related resources, processes, and outcomes. 
One might fruitfully juxtapose an analysis of black rage, necropolitics, and black time to one focusing on white narratives of exposure to black threat and victimization. Sociologist Kristen M. Lavelle conducts qualitative interviews with 40 older Greensboro, South Carolina residents. These are individual who are old enough to have some direct adulthood exposure to civil rights demonstrations, protests, and school desegregation efforts. They find that this group largely understands themselves as having had to worry about threats to the social order from demanding blacks, these whites who otherwise tend to recall themselves as having been willing to treat blacks as equals. For them, the anxieties and ultimate costs of social change were foisted upon them by unruly, overreaching blacks.

Three articles focus on issues of special relevance to Latinos in the U.S. Sociologists Marylee Taylor, Maria Krysan and Matthew Hall examine how intergroup contact interacts with other beliefs and perceptions to influence the favorablity of policy views toward immigrant and immigration. Drawing on data from a 2010 sample survey of Chicago area residents they do find that intergroup contact improves attitudes toward immigrants. However, there is an important interaction effect with perceived disadvantage or discrimination faced by immigrants. Here the results are consistent with an earlier line of argument from James Kluegel about whites' opposition to affirmative action for black (Kluegel 1985). They find that contact matters much more among those nonHispanic whites inclined to see Latino \as as facing unfair hurdles and hardly at all for those who deny such challenges exist. They read the results as consistent with a group position theory of prejudice (Blumer 1958; Bobo and Tuan 2006), wherein the denial of racial discrimination is part of an ideological outlook that defends a privileged group position in society.

Sociologist Daisy Verduzco Reyes examines the contextual dependence of patterns of panethnic identity among Latino college students. Based on a rich body of ethnographic observation, 80 surveys and 60 in-depth interviews across three types of campuses: a liberal arts college, a public research university, and a regional public university. Her research suggests that the experiences of group boundaries (ascriptive imposition) and more individual identity preference and meaning are a function of campus demography and the organizational environment, that result in a unique racial climate on campus. Latino identity was at its most solidaristic in a context of a white majority and affluent student body. Panethnic identity waned a bit in more diverse environments and yielded almost entirely to national origin identities in highly diverse and more working class college environments.

Sociologist G. Cristina Mora conducted intensive field research to examine the potential emergence of a panethnic Latino identity outside the borders of the U.S. Focusing on Barcelona, Spain, Mora draws upon both a period of extended participant observation and in-depth interviews with 52 immigrant leaders, party operatives, and bureaucrats. She finds that there is an important emerging panethnic Latino identity in Barcelona. However, rather than hinging on governmental classification policies and practices this identity is heavily bound up with party politics. This glimpse into panthenic identity formation thus suggests some different social mechanisms that may spark and sustain panethnic identifications.

Scholar Danielle Casarez Lemi and Augustine Kposowa examine how membership in an interracial relationship may (or may not) shape racial and political views among a sample of Asian Americans. The evidence suggests Asian Americans in relationships with whites are no less likely to be concerned with race issues than their endogamous peers. Indeed, the exogamous Asians are slightly more likely to rate race issues as among the nation's top priorities. Like a growing body of work, they raise questions about whether intermarriage should be read as the ultimate dissolution of racial identities and boundaries. 
In the current American political moment, which has some parallel echoes in other parts of the world (e.g., Brexit, growing potency of far right parties in other European countries), there are worrisome signs of erosion in the ties needed to keep a diverse democratic society healthy and whole. Certainly the scholarship in this issue does not paint for us a picture of easy racial harmony and integration in the present or near-term future. The challenges identified here were many, including:

- evidence of long stagnated hopes for occupational mobility;

- on-going feels of oppression and rage;

- an Obama presidency always shaped by and working within racial constraints;

- racial gaps in faith in the courts, including the highest court in the land;

- a criminal justice system that is seen as largely fair by most of the whites working in it whereas seeing unfairness is a critical precondition for supporting less punitive lines of reform;

- on-going police shootings of black men, including unarmed ones, resulting cases only selectively attended to by the media;

- the era mass incarceration, the carceral state, and stop and frisk arguably rising to a level of a form of necropolitics;

- whites convincing themselves that they are the victims of black demands and civil rights era excesses;

- intergroup contact only really improves policy views about immigration among those who perceive immigrants as receiving unfair treatment;

- micro-aggressions against Latino \as on college campuses continue with these students dependent on the local organizational and demographic context to provide resources for positive identity sustaining lines of response.

Nonetheless, the research in this issue of the Du Bois Review does equip us with the facts, the concepts and perspectives, as well as the theoretical tools necessary to resist the challenges now facing multiracial democracy. The latter project remains a viable and worthy ambition, with social scientific knowledge and theory a critical element in the tool kit for rising to the challenges to democracy in our times.

\section{REFERENCES}

Baldwin, James (1963[1992]). The Fire Next Time. New York: Vintage

Blumer, Herbert (1958). Race Prejudice as a Sense of Group Position. Pacific Sociological Review 1:3-7.

Bobo, Lawrence and Mia Tuan (2006). Prejudice in Politics: Group Position, Public Opinion, and the Wisconsin Treaty Rights Dispute. Cambridge: Harvard University Press.

de Tocqueville, Alexis (1848[1966]). Democracy in America. New York: Harper.

Dyson, Michael Eric. (2016). The Black Presidency: Barack Obama and the Politics of Race in America. New York: Houghton Mifflin Harcourt.

Glaude, Eddie (2016). Democracy in Black: How Race Still Enslaves the American Soul. New York: Crown.

Grier, William H. and Price M. Cobbs (1968). Black Rage. New York: Basic Books.

Harris, Fredrick (2012). Barak Obama and the Rise and Decline of Black Politics. New York: Oxford University Press.

Jeffries, Michael P. (2013). Paint the White House Black: Barack Obama and the Meaning of Race in America. Stanford, CA: Stanford University Press.

Katz, Michael B., Mark J. Stern, and Jamie J. Fader (2005). The New African American Inequality. Journal of American History 92(1): 75-108.

King, Desmond S. and Rogers M. Smith (2011). Still a House Divided: Race and Politics in Obama's America. Princeton, NJ: Princeton University Press.

Kluegel, James R. (1985). “If There Isn't a Problem, You Don't Need Solution: The Bases of Contemporary Affirmative Action Attitudes. American Behavioral Scientist 28: 761-784. 